revista ANTHROPOLÓGICAS

Ano 21, 28(1):8-40, 2017

\title{
As Plêiades e Escorpião na Cosmologia Barasana
}

\author{
Stephen Hugh-Jones ${ }^{\mathrm{a}}$
}

O texto apresenta detalhes etnográficos do sistema astronômico dos ameríndios da região do Noroeste Amazônico, a partir do entendimento dos Barasana do Rio Pirá-Paraná da bacia hidrográfica do Rio Uaupés em território colombiano. Os Barasana acreditam que o universo seja composto de três camadas básicas: o céu, a terra e o mundo subterrâneo, expressos como modelos da experiência terrena, de modo que cada um é descrito como tendo florestas e rios e habitado por pessoas nas grandes casas comunais ou malocas. Para os Barasana, o conhecimento astronômico não é simplesmente um sistema cognitivo, mas também aquele que dá ao homem poder sobre o mundo natural. A última parte do artigo é uma revisão da literatura atualizada sobre a astronomia cultural da região conhecida como a do Alto Rio Negro.

Barasana; Noroeste Amazônico; Etnoastronomia; Plêiades; Astronomia Cultural.

Em 1905, o etnógrafo alemão Koch-Grünberg publicou um relatório de um sistema astronômico indígena da região noroeste da Amazônia ${ }^{1}$. Seu relato, baseado em desenhos de dois informantes indígenas, permaneceu uma das descrições mais abrangentes da etnoastronomia das planícies da América do Sul. Referências dispersas à tradição das estrelas nos trabalhos de outros escritores ${ }^{2}$, juntamente com as próprias listas de palavras de Koch-Grünberg das muitas línguas

a Professor do Departamento de Antropologia Social da Universidade de Cambridge, Inglaterra. Email: sh116@cam.ac.uk. 
faladas na área ${ }^{3}$, sugerem que os elementos básicos do sistema que ele descreveu são provavelmente comuns a todos os indígenas falantes do Tukano da bacia do Rio Uaupés, e seus vizinhos de língua Arawak ao norte. Em seu relato, Koch-Grünberg identifica cerca de dezessete estrelas e constelações nomeadas e afirma que o conhecimento da astronomia é usado no cálculo do tempo, na orientação e na regulamentação das atividades agrícolas. Mas pouca informação é dada, por ele ou por outros escritores, sobre como esse conhecimento é usado e como ele se relaciona com a cosmologia e visão de mundo dos índios envolvidos. Neste artigo, tentarei responder a algumas destas questões com referência aos Barasana.

Os Barasana são falantes de uma das línguas da família linguística Tukano que vivem no Rio Pirá-Paraná, na região colombiana da bacia do Rio Uaupés ${ }^{4}$. A sua subsistência é baseada na agricultura de corte e queima de roças da cultura da mandioca, da pesca, da caça e da coleta. Como muitos povos indígenas, eles acreditam que vivem no centro do mundo. No caso deles, vivendo diretamente na linha do equador, essa crença recebe algum apoio objetivo pelo fato de que, duas vezes por ano, eles veem o sol diretamente sobre a cabeça ao meio-dia e, à noite, as estrelas parecem girar em torno da terra em caminhos retos indo de leste a oeste pelo zênite. $\mathrm{O}$ sol vertical, a marca da orientação leste-oeste dos fenômenos celestes e o fato de que, nessa área, os rios tendem a fluir de oeste para leste, todos desempenham papéis importantes no ritual e cosmologia desses índios.

Eles acreditam que o universo seja composto de três camadas básicas - o céu, a terra e o mundo subterrâneo - e cada camada é comparada com as placas cerâmicas redondas nas quais o beiju (pão de mandioca) é cozido. O céu e o mundo subterrâneo são modelados na experiência terrena, de modo que cada um é descrito como tendo florestas e rios e habitado por pessoas. As grandes casas comunais ou malocas dos Barasana, cada uma contendo cerca de vinte a trinta indivíduos, são representações do seu cosmos. $\mathrm{O}$ telhado é o céu sustentado pelas colunas da casa, que são montanhas, e os pontos 
de luz, onde o sol brilha através de buracos na palha escurecida pelo fumo, são as estrelas. $O$ chão é a terra, com limites definidos pelas paredes, um anel de montanhas como as bordas viradas para cima da grelha de mandioca, e embaixo está um outro mundo com o seu rio subterrâneo. Como o cosmos, a casa é conceitualmente (embora nem sempre realmente) orientada ao longo de um eixo leste/oeste. A porta da frente usada pelos homens está no leste e a porta das mulheres na parte traseira está no oeste. De oeste a leste, no meio da casa corre um rio invisível, a neste caso a 'contraparte' do rio Pirá-Paraná que divide o mundo. Na estrutura do telhado, um longo feixe horizontal chamado 'caminho do sol' (muhihu ya ma) corre de leste a oeste. O centro da casa, reservado para os homens e para os rituais públicos, é o centro do mundo, e acima dele no telhado está um poste vertical chamado 'sede do sol' (muhihu ya bota), um nome que também se refere ao meio-dia.

De acordo com o mito de criação, os primeiros seres, ou Povo do Universo (ümüari masa), o sol, o céu, a lua e as estrelas, foram criados pelo Sol Primordial (Yeba Hakü) como seus filhos. A criação dos seres humanos que os seguiram é apresentada como um processo que envolve a morte desses primeiros seres e seu subsequente retorno à vida imortal, em um mundo de espaço e tempo que é oposto ao dos homens mortais. Na terra, os rios correm de oeste a leste, enquanto que aqueles acima e abaixo correm de leste a oeste. Quando é dia na terra, é noite no céu e no mundo subterrâneo; e os mortos em um domínio estão vivos em outro de modo que, no mito, as estrelas mortas enterradas no céu caem na terra para casar com mortais vivos e os mortos enterrados na casa vão para o mundo subterrâneo, onde se tornam espíritos vivos. Por sua própria presença, o sol e as estrelas unem o passado com o presente e seus movimentos, no espaço e no tempo, unem uma série de princípios opostos sobre os quais depende a fertilidade e a continuidade do universo. Eles unem os vivos com os mortos, o oriente com o ocidente, homens com mulheres, terra com água, a estação chuvosa com a seca, e o que está acima e o que 
está embaixo com a terra no meio. Significativamente, o próprio casamento, do qual dependem tanto a reprodução sexual como a social, é também visto como uma união entre diferentes domínios espaciais. Os Barasana são um grupo exogâmico classificado como Pessoas-daTerra. Eles se casam com os Tatuyo que são Pessoas-do-Céu e os Bará que são Pessoas-da-Água.

Os movimentos diários e anuais do sol e das estrelas estão ligados tanto na experiência direta quanto na metáfora. $\mathrm{O}$ sol (muhihu) e seus filhos, as estrelas (nyokoa), giram em torno da terra cada dia, viajando de leste a oeste no céu e, em seguida, de oeste a leste até o rio do mundo subterrâneo abaixo. A alternância entre a noite e o dia está metaforicamente ligada àquela entre a estação chuvosa e a seca, de modo que o sol opaco da estação chuvosa às vezes é apresentado como um ser diferente de sua contraparte irmã brilhante e pode ser identificado com a lua. As estrelas, em suas passagens noturnas, também repetem seu movimento anual de leste a oeste, e cada ano se diz que regressam ao leste como bandos de aves migratórias, cuja passagem corresponde à configuração heliocêntrica de constelações particulares. As Plêiades retornam como tristes-pias (Dolichonyx oryzivorous), cinturão de Orion e espada como pequenas aves pretas que comem sementes não identificadas, e outras constelações como garças (Egretta thula).

Embora se diga que todas as estrelas são pessoas, apenas algumas são selecionadas para receber nomes e identidades individuais. Destas, a maioria encontra-se ao longo da Via Láctea ou Caminho das Estrelas (nyokoa $\mathrm{ma}$ ), que está perto, mas distinto, do caminho do sol (muhihu ya ma). Embora o caminho geral das estrelas seja de leste a oeste, a orientação diagonal da Via Láctea em relação à eclíptica serve para dividir o Caminho das Estrelas em dois segmentos, um Novo Caminho (mama ma) que vai de sudeste a noroeste e um Velho Caminho (bükü ma) que funciona do nordeste ao sudoeste. Diz-se que o Velho Caminho veio à existência antes do Novo, mas hoje é o Novo Caminho que precede o Velho no ciclo anual. 
Quando questionados sobre eles, os Barasana frequentemente listam estrelas e constelações em ordem sequencial. Essas listas, que geralmente começam com as Plêiades, que marcam o início do ano, relacionam a sucessão de estrelas com a das estações, que são nomeadas diretamente como estrelas ou como frutos de árvores que têm suas contrapartes celestiais. Antes de discutir alguns dos princípios ordenadores de sua astronomia, seguirei o exemplo Barasana e delinearei seu zodíaco sob a forma de uma lista (Figuras 1 e 2).

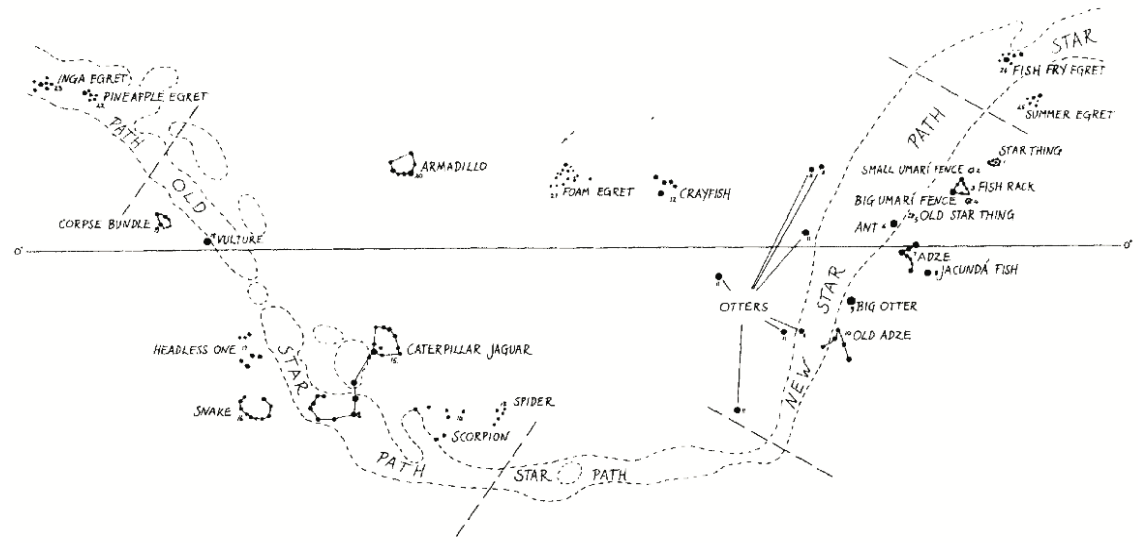

Figura 1. O zodíaco Barasana.

No início do Novo Caminho está (1) a Estrela Coisa (nyokoaro) ou Plêiades. Após do que vem (2) a Cerca Pequena do Fruto de Umarí (wamü saniro kihiika), um conjunto circular de estrelas a um lado do Hyades, provavelmente na região de $\boldsymbol{v}, \boldsymbol{\chi}$, e $\omega$ de Taurus; seguida (3) do Jirau de Peixe (wai kasabo), o triângulo do Hyades; logo (4) a Cerca Grande do Fruto de Umarí (wamü saniro haigü), um grupo no outro lado do Hyades perto do $\pi$ de Taurus e igualmente circular na forma; logo vem (5) a Velha Estrela Coisa (nyokoaro büküra), um grupo de estrelas emparelhadas com a Estrela Coisa e provavelmente a cabeça de Orion ( $\lambda$, $\phi 1$ e $\phi 2$ de Orion); segue (6) a Formiga-Saúva (mekahiamü), 
Betelgeuse (a de Orion), cuja cor avermelhada é comparada à da formiga; segue (7) o Enxó (siorühü), o cinto e a espada de Orion. Esta constelação em forma de cotovelo representa os enxós de pedra-lâmina que antes eram usados como ornamentos rituais usados sobre o ombro esquerdo na dança, mas que agora desapareceram completamente ${ }^{5}$; segue então (8) o Peixe Jacundá (Chrenichicla sp. muha buhua), Rigel ( $\beta$ de Orion); logo (9) a Lontra Grande (Pteronura brasiliensis - timi haigü, maha hesaü), Sirius ( $\alpha$ de Canis Major); logo (10) o Velho Enxó (siorühü büküra) provavelmente $\delta$, $\mathcal{\varepsilon}$, e $\boldsymbol{\eta}$ de Canis Major e emparelhado com 7 acima; seguem (11) as Lontras Pequenas (Lutra sp.) - (wania timia, ria timia), cada uma é estrela brilhante única e incluindo Procyon, Castor, Pollux e vários outros além de Sirius; Finalmente (12), o Lagostim (rasikamü) está incluído neste grupo e provavelmente faz parte de Leão.

Liderando o Caminho Velho (13) está a Aranha Venenosa (bühü), provavelmente um grupo de estrelas na porção superior de Centauro; segue (14) o Escorpião (kotibaha), provavelmente partes de Centaurus ou Lupus; logo (15) a Lagarta Onça (iya yai), Escorpião, mas às vezes com partes de Lupus e Libra adicionado como pés; em seguida (16) a Serpente Venenosa (anya), que é identificada geralmente com Corona Australis mas às vezes outras serpentes, todas as espécies de Jararacas, são dadas como estrelas ou grupos da estrela próximo; segue (17) o Sem Cabeça (rihoa mangü). Este é o cadáver decapitado de uma águia chamada Wekomi, o mítico sogro de Vênus da Manhã (busuri nyoko) e Vênus da Tarde (nyamikarima), cuja cabeça foi cortada por engano por sua própria filha Cobra Estrela (nyoko anya), uma das cobras mencionadas acima; segue (18) o Urubu (yuka), Altair ( $\alpha$ Aguila), uma estrela que anunciou a temporada para atacar e matar quando a guerra ainda era praticada; em seguida (19) o Pacote de Cadáveres (masa hoti), Delphinus, que é o corpo de uma mulher-estrela morta por um enxame de vespas, às vezes identificado com as Plêiades. Ela caiu na terra, voltou à vida e se casou com um mortal que foi com ela para o céu, apenas para ser morta por outra estrela na forma de uma cobra. 
Uma linha não identificada de estrelas nas proximidades é a escada da videira na qual eles viajaram. Por fim, (20) o Tatú (hamo), Corona Borealis, está incluído nesse grupo, embora seu lugar na sequência varie de acordo com diferentes informantes. ${ }^{6}$

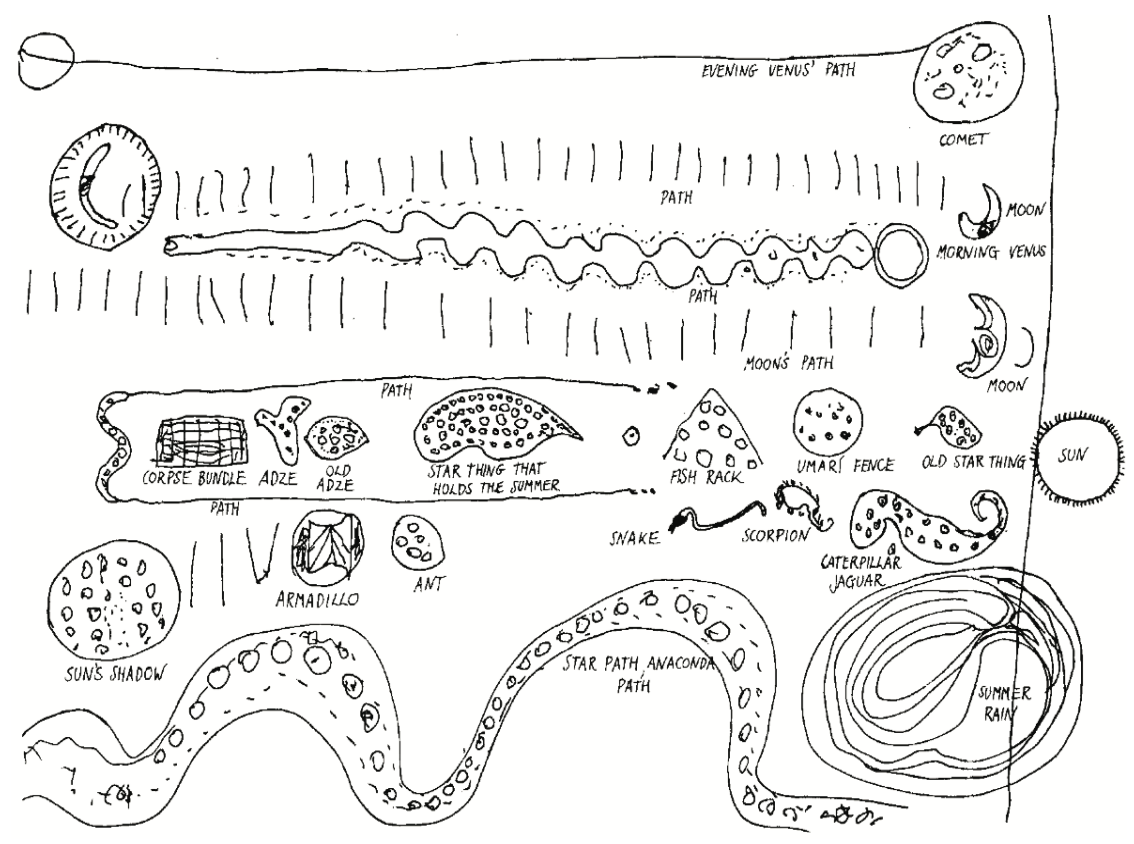

Figura 2. Os corpos celestiais desenhados por um xamã Barasana.

Além destes dois grupos principais, várias outras estrelas e constelações são reconhecidas e nomeadas, a maioria delas sendo garças ou frutas da floresta. Eleas têm em comum o fato de que estão entre os dois Caminhos da Estrela e o fato de que eles estão todos ligados com a chuva e a água. É como se elas servissem para reintroduzir um elemento de continuidade em um ciclo anual dividido em duas metades pela divisão da Via Láctea. Voltarei a este ponto. 
Tomados em conjunto, a maioria dos nomes de estrelas e constelações relatados por Koch-Grünberg de outros lugares na região do Uaupés correspondem de perto aos Barasana embora, em alguns casos, as estrelas a que se aplicam diferem. Esses nomes revelam certos padrões: referem-se a um número relativamente pequeno de classes, principalmente pássaros, frutas, insetos, peixes e outras criaturas aquáticas e alguns objetos de fabricação humana. Notavelmente ausentes estão todas as estrelas nomeadas como animais de caça que são caçados para o alimento. Eu sugiro que isto tem a ver com o fato de que os animais de caça são firmemente classificados como pertencentes à terra - no mito eles são apresentados como os parentes de um herói chamado Yeba, cujo nome significa Território - e, como tal, eles se opõem às criaturas do acima e abaixo, o céu por um lado e a água e o mundo subterrâneo do outro. É provavelmente também relacionado ao fato de que, da agricultura, da caça, da pesca e da colheita, a caça é a atividade produtiva menos afetada pelas mudanças sazonais.

Cada Caminho da Estrela tem uma constelação focal, sendo os outros descritos como seus 'companheiros' e são estes que recebem o maior grau de elaboração simbólica. A Coisa da Estrela ou Plêiades, líder do Novo Caminho, é a constelação mais importante no zodíaco Barasana. Como a Mulher Xamã (Romi Kumu), que é o céu, a criatura e o primeiro xamã, as Plêiades figuram de forma proeminente no mito e simbolismo ritual e seus movimentos regulam as calandras sazonais, agrícolas e rituais. A Coisa da Estrela é uma mulher, a Mulher da Estrela cujas oito estrelas são oito tiras de madeira como aquelas usadas para atear fogo à madeira seca de um local desmatado ou roça. Cada faixa é marcada com bandas alternadas de vermelho e preto: o vermelho é o fogo de um roça ardente que ilumina o céu oriental e traz a estação seca e o preto é o carvão que permanece depois que o fogo está fora e é a escuridão, céu nublado da estação chuvosa. A Mulher da Estrela, as Plêiades, controla assim as estações e a agricultura. Em novembro, ela aparece no crepúsculo no horizonte oriental e anuncia 
o fim das chuvas e o início do ciclo de desmatamento, a clareira da floresta feita por homens; Acima de janeiro e fevereiro, ela marca a estação seca quando as roças são queimadas; E em abril, quando ela se põe no oeste ao anoitecer, marca o fim da estação seca e o início de fortes chuvas que fertilizam a mandioca plantada nas roças pelas mulheres ${ }^{7}$. A vara de fogo da Mulher da Estrela é também o sol do verão, que é extinto pelas chuvas e as Plêiades como um todo são vistas como uma contrapartida do sol.

As duas épocas de frutificação da árvore do ingá (Ingá dulcis L.) coincidem com o nascer da noite e o conjunto das Plêiades e o mesocarpo doce e branco de seu fruto é comparado ao branco brilhante desta constelação. Similarmente, a época de frutificação do umarí (Poraqueiba sericea), outra fruta cultivada, coincide com as duas constelações que trazem seu nome. Além das frutas, as constelações do Novo Caminho estão todas associadas com o próprio alimento - formigas, peixes e camarões - ou com sua produção - roças, enxós e jiraus de peixe - e seus consumidores - as lontras. Como companheiras das Plêiades, estas estrelas estão ligadas coletivamente com a estação seca de dezembro a março e são descritas como sendo 'boas', uma avaliação consistente com sua associação com uma época do ano em que a comida é abundante e quando muitas visitas e banquetes acontecem. Esta é também a época do sol de verão.

Se as conotações do Novo Caminho forem positivas, as do Velho Caminho são igualmente negativas. As primeiras quatro constelações, Aranha, Escorpião, Cobra e Lagarta Onça, são todas criaturas venenosas. (Muitas das lagartas da Amazônia causam irritações na pele e algumas podem causar doenças graves). Além de serem venenosas, essas criaturas também são consideradas veículos de ataque por feitiçaria. Os quatro seguintes, o Sem Cabeça, Pacote de Cadáver, Urubu e Tatú, estão todos ligados à morte, sepulturas e putrefação, e os mitos sobre eles dizem respeito a contos de feitiçaria. Deve-se acrescentar aqui que, nos eclipses lunares, diz-se que a lua desce à terra na forma de um tatú que escava sepulturas e devora 
os ossos dos mortos - perto da constelação Tatú estão três estrelas numa linha que são chamadas de 'Osso do Tatú'. O Velho Caminho é descrito como velho, desgastado e decadente e suas estrelas como ruins. Novamente, isso é consistente com o fato de que eles dominam o céu durante a estação chuvosa de abril a novembro, quando a comida é escassa, a vida social é reduzida, e as pessoas são propensas a doenças. Este é o tempo do sol de inverno, que é obscurecido por nuvens e chuva.

A constelação focal deste grupo, a Lagarta Onça ou Escorpião, é uma criatura muito ambivalente, várias vezes descrita como um onça com uma cobra para uma cauda ou como uma cobra com onça apenas para um nome. Como onça, ela está ligada ao Onça da Fruta Florestal (hee rika yai), o mestre dos frutos da floresta, e um conjunto de estrelas na região de $\zeta$ de Escorpião, chamado de 'testículos de onça', também são identificados com fruto de árvore. Como uma cobra, a constelação é identificada com a categoria hino, que abrange tanto grandes constritoras não venenosas (Boidae) e também figuras míticas de antepassados de quem uma cobra é apenas uma manifestação. Os ovos desta serpente são o conglomerado de $\zeta$ de Escorpião e sua língua é a lâmina do enxó ritualístico, ela mesma uma constelação (ver acima). ${ }^{8}$ Esta constelação é uma manifestação da Anaconda Juruparí (hee hino), cujo representante terrenal é o Boa do arco-íris (Epicrates cenchris). Uma constelação de serpentes identificada com Escorpião é encontrada em toda a região da bacia do rio Uaupés e, em muitas partes da Amazônia, Escorpião é identificada com Boiassu, a Grande Serpente 9 . A Lagarta Onça é o 'pai das serpentes' (anya hakü) e é responsável por sua criação. Como ele e seu companheiro, a serpente passa seu zênite e começa a se estabelecer em outubro. Cobras tornam-se especialmente visíveis e agressivas e este é presumivelmente o momento em que muitas delas procriam.

Vários escritores relataram uma constelação de onça-pintada para a região do Uaupés e Koch-Grünberg identifica este onça com Cetus $^{10}$. Esta constelação, e especialmente seus bigodes (Cetus e outras 
estrelas), está associada a chuvas violentas. Os Barasana associam a Lagarta Onça com chuva e tempestades, quando começa a pôr-se no crepúsculo, um período que corresponderia grosso modo à elevação noturna da cabeça de Cetus. É como se, na Lagarta Onça, os Barasana fundiram os valores e associações de duas constelações diferentes, comuns a toda a região de Uaupés, em uma só.

O período de junho a agosto, quando a Lagarta Onça sobe mais e mais alto no céu ao anoitecer, é o momento em que muitas espécies de borboleta e mariposa (badi iya - Noctuidae; iya hoa küna - Automeris sp. etc) procriam. Como estas lagartas começam a se tornar crisálidas, eles vêm para baixo das árvores em que se alimentam e se tornam um item significativo na dieta Barasana em uma época do ano em que outros alimentos são escassos. A Lagarta Onça é também o 'pai de lagartas' e é responsável por seu aumento. Seus filhos, o Povo Lagarta (iya masa) têm pêlos coloridos e corpos brilhantemente padronizados que são comparados aos ornamentos de penas e pintura corporal que os homens usam em danças. $\mathrm{O}$ rápido crescimento e metamorfose das lagartas é uma metáfora apta da regeneração e da continuidade através da mudança, e suas danças são usadas para manter as estações se movendo. Mas, além de fornecer comida, essas lagartas são criaturas perigosas que enviam doenças e morte aos seres humanos. São delas a estação de tempestades, trovões e relâmpagos, que são veículos de feitiçaria. Como um informante colocou, "eles querem que nos tornemos amigos e nos juntemos a eles em suas danças para que eles nos chamem. Se respondemos, nossa alma (üsü) é tirada, nós nos juntamos a eles e morremos. Se sonharmos com uma onça-pintada neste momento, é a Lagarta Onça que desce para comer nossas almas”. As lagartas pertencem ao mundo acima e têm apenas uma existência temporária na Terra. Eles vêm do mundo dos mortos e estão vestidos com trajes de espíritos, os ornamentos que os seres humanos usam para entrar no mundo espiritual em danças.

O contraste entre a Coisa das Estrelas (as Plêiades) e a Lagarta Onça (Escorpião) e entre suas respectivas estrelas companheiras pode 
agora estar relacionado com o calendário sazonal Barasana (Figura 3). $\mathrm{O}$ ano é dividido em períodos de hue: chuva pesada, águas altas, e céus nublados e períodos de küma: pouca chuva, pouca água e tempo ensolarado. Küma também significa 'ano' e, em um extremo, o contraste entre küma e o hue é entre a estação seca principal de dezembro a março e o resto do ano, que é relativamente molhado. Em termos brutos, esse contraste é equivalente ao que existe entre as Plêiades e Escorpião, pois são visíveis durante épocas opostas; quando um está no zênite, o outro está em seu nadir. No outro extremo, estes termos são usados para se referir a qualquer período (mesmo muito curto) de sol ou de chuvas pesadas.

O ciclo anual começa com o nascer noturno das Plêiades, que anuncia a estação seca e a estação de frutos cultivados. A Coisa da Estrela está associada com o fruto ingá (ver acima), e uma heroína do mito chamada Mulher Ingá (Meneridyo) é identificada com a Coisa da Estrela Velha, uma constelação emparelhada com as Plêiades ${ }^{11}$. Como as Plêiades sinalizam frutos, as constelações de frutas umarí 'lembram' as pessoas para cercar suas árvores para proteger a fruta que cai de animais selvagens. $O$ fim da estação seca é marcado por rajadas curtas de chuva pesada chamadas chuva de verão (küma oko) e é um momento de crescimento excepcional e fertilidade. A chuva desencadeia os voos de criação de formigas saúva comestíveis (Atta sp.) E coincide com o tempo que a estrela Formiga (Betelgeuse) passa seu zênite. A chuva e as águas ascendentes também precipitam a desova de muitas espécies de peixes e rãs comestíveis (Leptodactylus e Osteocephalus sps.) que são facilmente capturadas neste momento. $O$ verdadeiro fim da estação seca em abril é um tempo de chuva muito forte e rios inundados. As primeiras grandes chuvas são chamadas de chuvas da Coisa da Estrela (nyokoaro hue), depois das Plêiades, que estão então definidas no oeste ao anoitecer. A seguir seguem uma série de chuvas, nomeadas como as constelações Cerca da Fruta Umarí, Formiga Saúva, e Enxó, que vêm um após o outro neste momento. 


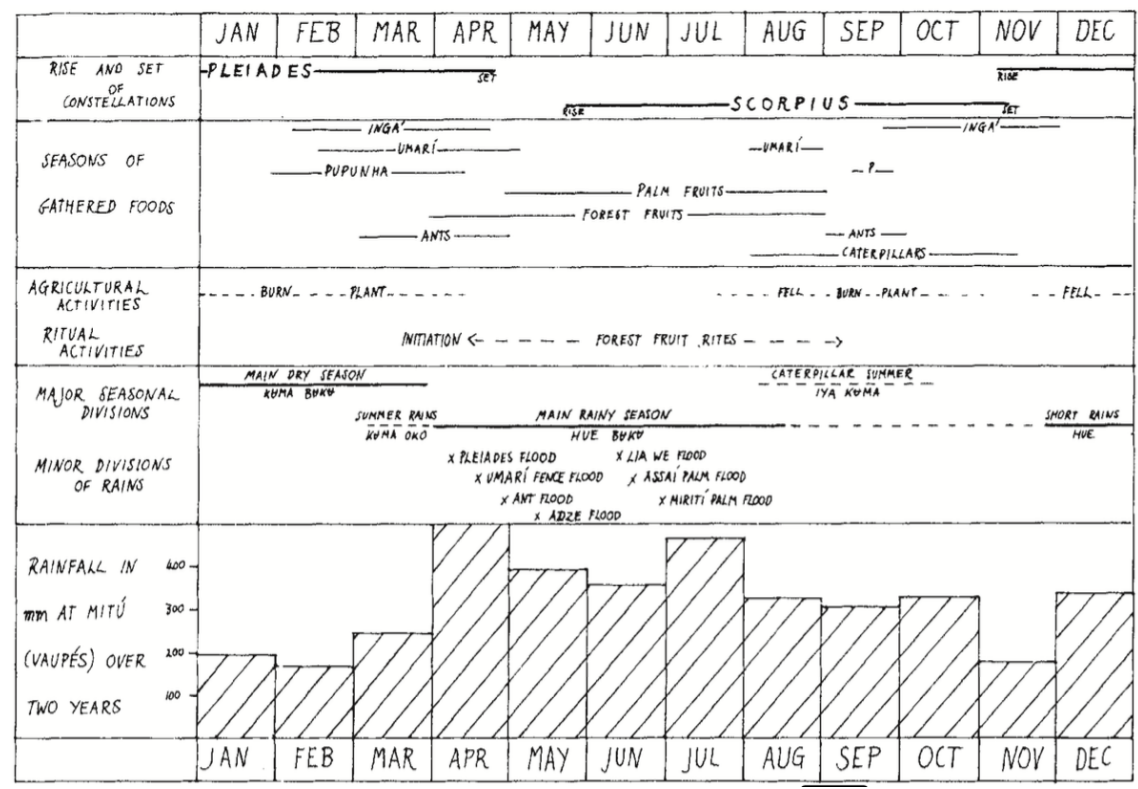

Figura 3. Calendário Barasana das estações. Informações pluviométricas tiradas do Atlas de Colombia (Bogotá: Instituto Geográfico 'Agustín Codazzi', 1969), p. 67.

Com as chuvas pesadas, os rios inundam e os cardumes do peixe de aracú (Leporinus sps.) sobem o rio para desovar. A Jirau de Peixe (Hyades), chamada 'jirau do homem' (masü ya kasabo) neste momento, 'lembra' as pessoas para colocarem armadilhas e se preparar para a abundância de peixes. À medida que as chuvas continuam e a jirau, agora chamada 'jirau das lontras' (timia ya kasabo), desce do céu, o peixe deixa de desovar e se torna escasso nos rios inundados. Esta escassez é atribuída às lontras, que vêm para baixo do céu para comer o peixe. A estação chuvosa principal é o momento em que as frutas selvagens da árvore, na maior parte espécies de palmeira, entram na época de colheita e são recolhidas em quantidades grandes em conexão com danças rituais. Os frutos de palmeira mais importantes, mirití (Mauritia flexuosa), açaí (Euterpe oleracea) e buritirana (koha, Mau- 
ritiella aculeata), dão seus nomes a subdivisões da estação chuvosa e cada um tem uma estrela ou constelação à qual corresponde. Infelizmente, eu ainda não sou capaz de dar identificações precisas para estas estrelas, embora todas elas pareçam estar em uma área ao redor de Corvus.

À medida que a cabeça da Lagarta Onça sobe mais alto no céu, as chuvas afrouxam gradualmente e, em torno do tempo em que atinge seu zênite em agosto, há um período de seca curto e variável chamado lagarta de verão (iya kuma), quando as lagartas se tornam maiores. Este período fino é como uma versão em miniatura da estação seca principal (küma buku). Os rios começam a diminuir, os frutos cultivados ingá, umarí e pupunha (Guilielma gasipaes), cujas principais culturas são em fevereiro e março, vêm brevemente na estação e as pessoas fazem chagras para plantar culturas de milho. Como no caso da longa estação seca, as chuvas que terminam este período seco desencadeiam os voos de criação de formigas e a desova de rãs e peixes. Mas, apesar de compartilhar alguns dos atributos positivos da estação seca, a lagarta de verão permanece uma época ambivalente do ano, pois o tempo é imprevisível, as tempestades são frequentes, e os alimentos são escassos e inerentemente perigosos. À medida que a Lagarta Onça e a Cobra Venenosa afundam no céu em outubro, as chuvas tornam-se pesadas e persistentes e os rios sobem, em um período chamado inundação de lagarta (ïya hue) e inundação de cobra (anya hue). Com o reaparecimento das Plêiades ao entardecer, em novembro, marcando o início do novo ciclo, as chuvas começam a diminuir e a estação seca começa.

No crepúsculo, homens, mulheres e crianças frequentemente se sentam em grupos familiares no espaço arenoso desobstruído na frente da maloca; este é o momento em que a maioria das observações das estrelas é feita. A atenção é focada na posição vertical de diferentes estrelas com respeito aos horizontes oriental e ocidental. Visto desta perspectiva, os movimentos das Plêiades e Escorpião mostram um padrão distinto, pois são visíveis em épocas opostas do ano e, em cada caso, a sua elevação traz o fim da chuva, o seu zênite marca uma 
estação seca e a sua descida para o horizonte ocidental coincide com o início das chuvas. Que a ascensão das estrelas pareça parar a chuva enquanto sua descida parece trazê-la pode ser relacionada às ideias a respeito da Via Láctea. A Via Láctea é descrita várias vezes como sendo um reflexo do Rio do Leite na terra ou como uma continuação desse rio no céu. O Rio Leite (ohekoa riaga) na terra é um enorme rio no leste, muitas vezes identificado com o Amazonas, ou Rio Negro. O céu é descrito como uma cúpula e comparado com as cabaças hemisféricas com interiores de vidros pretos usados para conter pó de coca. No horizonte, a cúpula do céu encontra a terra de modo que o Rio do Leite no céu é contínuo com aquele na terra. O leste, ou a porta da água (oko sohe) é dito igualmente ser como uma cachoeira que emite a água ao mundo abaixo quando a água que cai sobre os lados das montanhas de topo plano traz a água do mundo acima. À medida que os rios terrestres fluem de oeste a leste, enquanto que os do céu e do mundo subterrâneo fluem de leste a oeste, a totalidade faz um sistema fechado que circula continuamente a água através dos três domínios cósmicos (Figura 4). A água flui rio abaixo para o leste, onde é levada para o céu pela Via Láctea e derrubada novamente no outro lado no oeste. À medida que as constelações se elevam, elas tomam água da terra para causar uma estação seca e, ao descerem novamente, trazem água celestial como chuva. Como dia, a estação seca está conceitualmente localizada no leste, que é o domínio masculino no espaço doméstico; Como a noite, a estação molhada vem do oeste, o domínio das mulheres. A Via Láctea e a água são, portanto, mediadores entre domínios cósmicos e uniões de opostos. A água também é uma fonte de fertilidade que faz com que as plantas cresçam, as árvores produzam frutos e os animais se reproduzam.

Sugeriu-se acima que as constelações de garças pareciam mediar entre as duas metades da Via Láctea e, assim, manter sua continuidade. Um destes, (21) a Garça de Espuma (somo yehe - Coma Berenices), encontra-se a meio caminho entre os dois trajetos da estrela (Figura 1). As outras, (22) Garça de Abacaxi (sena yehe - partes de Lacerta), (23) 
Garça de Piaba (imika yehe - $\beta$ Perseus e estrelas circunvizinhas), (24) Garça de Verão (küma yehe - $\beta$ Perseus e estrelas circundantes). E (25) a Garça de Ingá (mene yehe - parte de Cassiopéia), todos estão em uma linha ao longo da Via Láctea entre o Velho Caminho e o Novo. Estas constelações e pássaros são fortemente ligados com água. A garça é chamada de 'mestre da água' (oko ühü) e acredita-se que traz o frio, névoas e chuva, e os pequenos grupos de garças migratórias que chegam a cada semana ou duas ao longo da estação chuvosa são comparadas à sucessão de chuvas. De um modo mais geral, as suas plumas (uga) de reprodução puramente brancas e em forma de névoa, muito valorizadas para a confecção de ornamentos de dança, estão associadas à Via Láctea. Elas foram criadas pela Mulher Xamã, que é ela mesma identificada com o céu e, em particular, com as Plêiades. Em vingança por seu roubo das sagradas flautas de Jurupari, seu irmão a fez menstruar e agora ameaçou matá-la. Para detê-lo, ela fez penas de garça de seus cabelos longos e fluidos e ofereceu-os para ele ${ }^{12}$. Essas plumas são a Via Láctea, que também é chamada de 'madeixa de cabelo' (nyokoa hoa hani). Este fragmento de mito sugere que há alguma conexão entre o cabelo e a menstruação, uma conexão que é feita de forma bastante explícita em outros contextos quando se diz que é o seu cabelo que faz com que as mulheres menstruem.

A conexão implícita entre a menstruação e a Via Láctea surge mais fortemente na associação feita entre os ciclos menstrual e sazonal. A estação chuvosa é o período menstrual do céu personificado pela $\mathrm{Mu}$ lher Xamã. Na estação seca, o mundo torna-se velho e cansado e é então refrescado e rejuvenescido pelas chuvas. A chave para este processo encontra-se nas Plêiades, que é identificado com uma cabaça de cera (werea koa) de propriedade da Mulher Xamã. A cabaça é sua vagina e a cera seu sangue menstrual, que derrete. A Mulher Xamã ofereceu aos homens a imortalidade na forma de sua cabaça, mas eles se recusaram a comer dela. Colocou a cabaça sob seu corpo e ali cobras, aranhas e escorpiões. Escorpião e seus companheiros vieram e comeram dele e podem assim derramar suas peles. A menstruação como uma mu- 
dança interna da pele é igualada com ecdise, uma mudança da pele externa. A marcha das estações é vista como um ciclo interminável de mudanças de pele, primeiro pela Mulher Estrela, as Plêiades e, em seguida, pela Lagarta Onça, Escorpião. Para as estrelas imortais, o ciclo de vida é apenas uma questão de mudança de pele, mas, para os seres humanos, é literalmente uma questão de vida ou morte ${ }^{13}$.

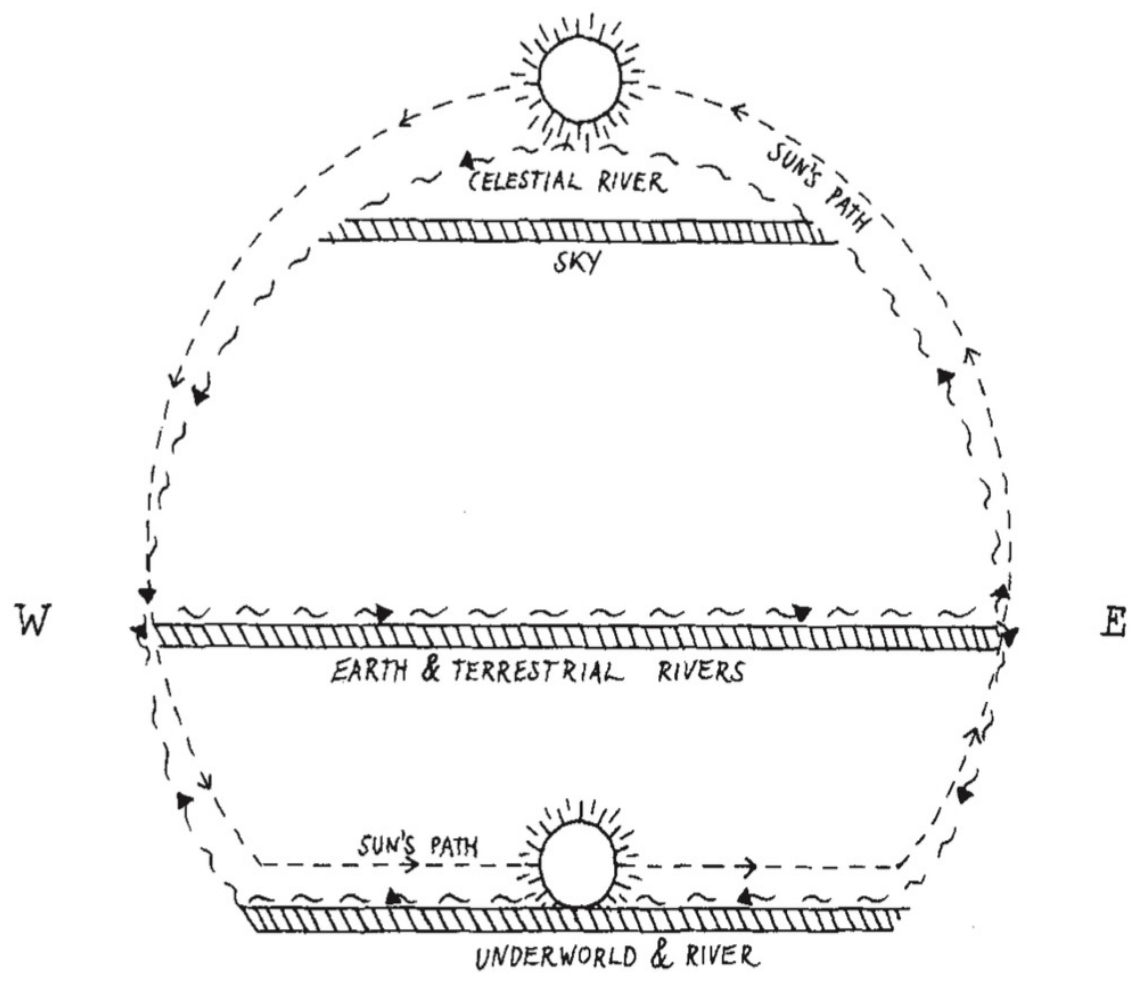

Figura 4. Circulação dos rios nas três dimensões da cosmologia Barasana.

O mito que citado aqui enfatiza a mudança de pele e a imortalidade, mas outra versão enfatiza o veneno e a morte. Neste, serpen- 
tes, aranhas e escorpiões comem de um pote de veneno curare para tornarem-se venenosas e a Mulher Xamã aparece como uma ogra sexualmente voraz, cujos pelos púbicos são feitos a partir de vinhas de timbó. As Plêiades e Escorpião são, portanto, opostas, mas cada uma também combina dentro de si os valores do seu oposto em proporções invertidas. As Plêiades vivificantes, visíveis na estação seca, quando a comida é abundante, também têm um lado sinistro e trazem a chuva como ela se põe. O Escorpião, capaz de causar a morte, visível na estação chuvosa quando a comida é escassa, anuncia uma estação seca curta e um alívio da fome quando ele sobe. Em resumo, o Escorpião aparece como uma contraparte da estação chuvosa das Plêiades e uma série de outros mitos, os quais são muitos para contar aqui, mas poderiam ser citados para apoiar esta afirmação.

Foi dito acima que as Plêiades são consideradas uma contraparte noturna do sol. A evidência para esta afirmação vem da identificação das Plêiades com a Mulher Xamã (Romi Kumu) e especificamente com uma cabaça da cera identificada como sua vagina. Esta cabaça de cera é também declarada ser o sol e, no mito, a Mulher Xamã é o proprietário do fogo, que ela mantém em sua vagina. Como Mulher Xamã, o sol também tem uma existência cíclica, tornando-se velho e cansado na estação chuvosa e aparecendo jovem e renovado quando a estação seca retorna. $O$ presente sol, princípio criador masculino, é filho do Sol Primordial (Yeba hakü) e, como as Plêiades, um princípio criador feminino, tem um duplo aspecto. O Sol Primal tinha dois filhos do sexo masculino, um mais velho do que o outro, que tinha uma discussão sobre quem deveria ser mais brilhante, mais velho e mais dominante do que o outro. Um deles ameaçou usar seu calor para explodir o mundo e fazer com que as mulheres se tornassem estéreis ao secar seus úteros. $\mathrm{O}$ outro, tirando o calor e a luz de seu irmão, prometeu garantir a fertilidade através de uma alternância regular entre o molhado e o seco. Em termos de ciclo anual, estes dois são o sol da estação seca e o sol da estação chuvosa, que, em nossos termos, são o sol do solstício de inverno e o sol do 
solstício de verão. Em termos do ciclo diário, eles são o sol e a lua, que são ambos chamados muhihu e distinguidos como ümüagü, 'do dia' e nyamiagü 'da noite'.

Somos assim apresentados com uma série de princípios opostos, molhados e secos, macho e fêmea, leste e oeste, dia e noite, acima e abaixo, selvagens e cultivados, vida e morte, que se aplicam a uma série de processos temporais, o ciclo de vida, o fluxo dos rios, o uso do espaço doméstico, as atividades agrícolas, etc. Mas é importante notar, em primeiro lugar, que embora o gênero desempenhe um papel importante nesses contrastes, eles não devem ser confundidos com, ou reduzidas ao sexo e, em segundo lugar, que, enquanto se fazem ligações metafóricas entre estes pares, estas ligações são contextuais e processionais e não fixas e estáticas. Assim, enquanto em alguns contextos o extremo oeste da casa é feminino e o extremo leste é masculino, em outros este contraste espacial pode se relacionar com aqueles entre hospedeiros e convidados, parentes e afins, ou homens e espíritos. Da mesma forma, enquanto as atividades agrícolas masculinas dominam a estação seca e as fêmeas a úmida, as Plêiades são mais do sexo feminino do que masculino e Escorpião mais do sexo masculino do que feminino. O significado dos corpos celestiais reside no fato de que, através de seus movimentos no espaço e no tempo, eles unem todos esses princípios opostos e isso explica sua natureza dual. Coisas que dão voltas e voltas, de cima para baixo em um cosmos em que pontos fixos opostos com valores opostos são obrigados a ter essa qualidade sintética e é precisamente isso que os torna objetos de poder e veneração para os Barasana.

Até agora, eu tenho falado principalmente em um nível teórico. Gostaria de concluir sobre uma nota mais prática indicando como os elementos do sistema acima descrito é posto em prática no contexto das danças rituais. Para os Barasana, o conhecimento astronômico não é simplesmente um sistema cognitivo, mas também aquele que dá ao homem poder sobre o mundo natural. Os xamãs que detêm esse conhecimento afirmam que lhes permite controlar o crescimento e a 
fertilidade para fins sociais e que, através dos procedimentos rituais apropriados, são eles que mantêm o cosmo em movimento. Nestas danças rituais, os ornamentos dos dançarinos, os movimentos que executam e o calendário ritual, todos se baseiam no sistema que descrevi para a sua eficácia simbólica.

Os ornamentos de penas usados nas danças permitem aos homens entrar no mundo dos espíritos e, portanto, eles estão intimamente associados com esse mundo. Por um lado, eles são usados como bens funerários e é dito que o rio do mundo subterrâneo (submundo) está inundado com eles. Por outro lado, eles são feitos em grande parte de penas de pássaro e pássaros, como vimos, que estão intimamente identificados com as estrelas que vivem no mundo imortal do céu. Os principais componentes do cocar dos dançarinos nos refletem os princípios opostos mencionados acima. $\mathrm{Na}$ frente da cabeça é colocada uma faixa semelhante a uma coroa de penas amarelas e vermelhas de arara - esta faixa representa o sol. Atrás, preso nos talos de folha de banana que agora substituíram os longos cabelos presos usados no passado, uma massa de plumas de garça branca é usada com duas asas de garça penduradas nas costas. Essas plumas e cabelos são as estrelas e a chuva e a totalidade dos ornamentos na cabeça representa uma síntese cósmica.

Os dançarinos dançam em uma linha, com um principal deles (baya) no meio, cercado por seus companheiros em cada lado, um arranjo remanescente da constelação focal e de seus companheiros em cada trajeto da estrela. A dança ocorre em uma casa que representa o cosmos; a linha de dançarinos dança em torno de um caminho que circunda uma área central identificada com o centro do mundo. A dança sempre começa no eixo central da casa na frente ou extremidade leste. De lá, a linha de dançarinos se move ao redor do caminho de dança para a esquerda ou direita, mas sempre para a parte traseira da casa e do oeste. Em seus movimentos em volta da casa, os dançarinos replicam assim a rotação leste-oeste do sol e das estrelas, que são representadas por seus ornamentos, sendo o plano vertical do cosmos 
transposto para o chão da casa em que dançam. Estas danças começam em um dia e devem durar toda a noite até o dia seguinte, com os eventos rituais mais importantes ocorrendo no crepúsculo, na meianoite, e no alvorecer. ${ }^{14}$

A rodada anual das estrelas e das estações também é replicada na rodada anual de danças que compõem o calendário ritual. Durante a estação chuvosa, à medida que os frutos da floresta amadurecem, cada espécie é trazida cerimonialmente na casa pelos homens que tocam as flautas sagradas de Jurupari (hee). O fruto é dado às mulheres e vem como um presente dos espíritos da floresta cujas vozes são os instrumentos que as mulheres estão proibidas de ver. Estes ritos (hee rika soria wii) são a ocasião para as práticas xamânicas destinadas a assegurar a continuidade das estações, a fertilidade das árvores e o amadurecimento da fruta. Nesse contexto, os ornamentos usados pelos dançarinos representam frutas da floresta, cada item representando uma espécie diferente, e os corpos dos dançarinos representam as árvores. Mais uma vez, vemos a ligação entre os ornamentos e as estrelas, pois, como explicado anteriormente, os frutos das árvores também têm suas contrapartes celestiais. No início da estação seca, o fruto cultivado, cujo amadurecimento coincide com a aparência das Plêiades, é levado à casa num rito semelhante ao dos frutos silvestres, mas que constitui a primeira fase da iniciação masculina. $O$ crescimento e a maturidade dos frutos simbolizam o crescimento desejado dos iniciados que são trazidos com eles. O resto da estação seca, quando a comida é abundante, é o momento para danças em que o peixe defumado e a carne são cerimonialmente trocadas entre as comunidades maloca relacionadas por casamento.

O clímax do calendário ritual ocorre no final da estação seca (março-abril), quando o rito principal de iniciação (hee wii) é mantido. O momento deste rito é determinado pela posição das Plêiades, que deve estar baixa no horizonte ocidental ao anoitecer. Assim, o rito coincide com a conjunção dos princípios opostos discutidos acima (estação seca - estação úmida, Plêiades - Escorpião, atividades agrí- 
colas masculinas - atividades agrícolas femininas, frutos cultivados frutos silvestres). Também coincide com o equinócio vernal, quando o sol está em equilíbrio entre seus extremos de estação úmida e seca e em posição vertical tanto à meia-noite como ao meio-dia e assim "sentado" diretamente em seu assento no centro da casa (veja acima). O mito da origem deste rito pode ser interpretado como fazendo referência tanto ao equinócio quanto à conjunção das posições zênite e nadir do sol. A história diz respeito a dois seres solares que viajam juntos até o rio do mundo subterrâneo. Ao meio-dia (meia-noite na terra), eles param, testam os poderes uns dos outros e concluem que eles são de igual força ${ }^{15}$.

Este ritual é o mais importante de todo o ciclo ritualístico e é, sobretudo, neste contexto que o espaço e o tempo humanos assumem proporções cósmicas. Durante o rito, os participantes cantam juntos continuamente, afirmando que estão em um com seus antepassados e fazendo o que seus ancestrais sempre fizeram. Eles tomam drogas alucinógenas que alteram suas percepções de espaço e tempo e dão acesso direto ao mundo retratado no mito. A casa, construída como uma réplica do cosmos, torna-se o próprio universo e o ciclo de noite e dia assume as proporções do ano. Ao mesmo tempo, as camadas do cosmos são unidas e os vivos são unidos com os mortos. Instrumentos sagrados que representam os ossos dos antepassados são tirados de seus esconderijos no fundo dos rios e trazidos até a casa. Lá eles são reunidos e ganham vida e voz pelos homens que os tocam. Em termos míticos, esses instrumentos vêm do mundo subterrâneo e são trazidos à vida na Terra.

O clímax do rito ocorre à meia-noite, quando dois homens que representam o sol e vestidos em traje completo tocam flautas sagradas para cima e para baixo no eixo leste-oeste da casa. Ao mesmo tempo, os iniciados comem pó de coca de uma abóbora sagrada de cera de abelha (werea koa). Essa cabaça de cera representa as Plêiades, o céu e a Mulher Xamã como um princípio feminino (ver acima). As flautas representam a Anaconda Juruparí (Hee Hino) e o Escorpião como um 
princípio masculino. Dado o momento do rito e a conjunção ritualizada de objetos sagrados que representam princípios opostos, mas complementares, agora deve ser fácil entender por que os Barasana acreditam que, se esse rito não fosse realizado regularmente, o universo chegaria ao fim.

\section{Posfácio: 33 anos depois}

A parte anterior deste artigo foi publicada pela primeira vez em 1982, quando a etnoastronomia ainda estava no seu início. Apareceu em Ethnoastronomy and Archaeoastronomy in the American Tropics, que foram editadas como atas por Tony Aveni e Gary Urton de uma Conferência Internacional, que ocorreu no Planetário Hayden do Museu Americano de História Natural, em Nova York, com patrocínio da Academia de Ciências de Nova York. Aveni e Urton foram verdadeiros pioneiros que abriram um novo campo interdisciplinar de pesquisa que reuniu astrônomos, antropólogos, arqueólogos, historiadores, entre outros, todos interessados no conhecimento astronômico entre as sociedades indígenas contemporâneas, em como os edifícios, assentamentos e monumentos arqueológicos estavam alinhados com eventos no céu e como tais alinhamentos correspondem a informações astronômicas contidas em códices antigos, outros documentos históricos e em relatos etnográficos contemporâneos.

Para começar, grande parte desse interesse se concentrava nas Américas e, com foco particular nas civilizações Meso-Americanas e Andinas, mas o volume editado por Aveni \& Urton (1982) estendeu o campo para incluir as regiões de planície da América do Sul. Essa tendência foi então continuada com Etnoastronomias Americanas (1987) de Arias de Grief e de Reichel, um volume editado que incluiu três artigos sobre o Noroeste Amazônico: dois sobre falantes do Tukano, o Cubeo (Correa 1987) e Tanimuca (Von Hildebrand 1987), e um sobre o Yukuna-Matapí falante do Arawak (Reichel 1987). Desde então, várias publicações têm sido dedicadas ao conhecimento astronômi- 
co dos povos da região do Rio Negro do Noroeste Amazônico. Além disso, informações importantes, mas dispersas, também podem ser encontradas em muitos outros trabalhos mais recentes. Aqui, Nahuri \& Kumaro (2003, sobre os Tukano), Romero Raffo (2003, sobre os Curripako) e Cabalzar (2008, sobre os Tuyuca) todos se destacam.

Um aspecto especialmente bem-vindo dos trabalhos de astronomia relacionados com a região do Noroeste Amazônico é que muitos deles foram escritos por autores indígenas, em parceria com coautores não-indígenas ou com autores por direito próprio que às vezes escrevem exclusivamente em suas próprias línguas indígenas. Ribeiro \& Kenhíri (1987, Desana), Oliveira, Cardoso \& Azevedo (2010, Tukano e Desana) e Cabalzar \& Azevedo (2010, Tuyuca) são exemplos de coautoria com pessoas de fora, enquanto Rojas Sabana (1997, Curripaco), AEITU (2005, Tuyuca), Diakuru \& Kisibi (2006, Desana), e AEITY \& ACIMET (2008, Tukano, Desana) são trabalhos de coautoria ou de autoria múltipla, escritos exclusivamente por especialistas indígenas.

Esta série de obras de autores indígenas está ligada a programas de investigação colaborativa envolvendo especialistas locais e cientistas de fora e abrangendo os domínios da Astronomia, Antropologia, Agronomia, Ecologia, Piscicultura e Cartografia. Esta pesquisa colaborativa constitui uma componente chave dos programas de Educação e Gestão Ambiental, que visam fortalecer o conhecimento cultural local que integra preocupações ecológicas, econômicas, sociais e rituais em um esquema cosmológico abrangente e que servem para garantir a transmissão desse conhecimento às gerações futuras. A ênfase desses programas na compreensão de como os diferentes ciclos sazonais dos mundos humano e natural estão integrados significa que eles dão lugar de destaque ao conhecimento astronômico. Aqui, a tese de Cardoso (2007) fornece um relato fascinante de oficinas astronômicas organizadas por um astrônomo profissional em conexão com um programa de etno-educação entre os Tukanos. Um dos principais resultados desses programas é os 'calendários ecológico-culturais', os 
diagramas circulares em papel ou cartão que mostram como os diferentes fenômenos cíclicos estão relacionados no tempo. Como pode ser visto nas Figuras 5 e 6, as constelações figuram de forma proeminente nestes diagramas de calendário como estações de indexação, níveis de água e fenômenos ecológicos.

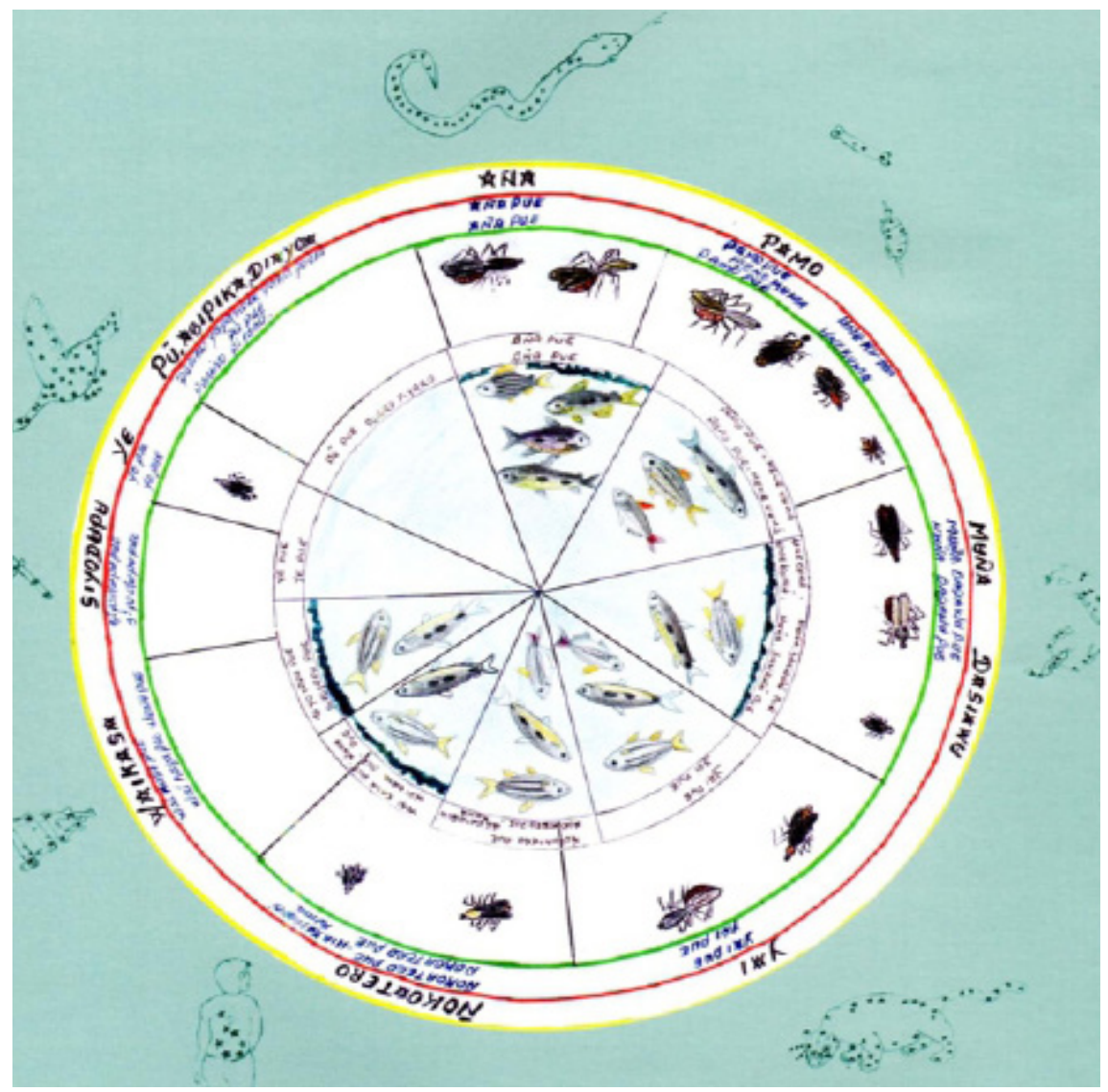

Figura 5: Calendário que mostra a correlação entre as constelações (periferia vermelha), os períodos de chuva pesada e alta que levam seus nomes (periferia interna verde), a desova de diferentes espécies de peixes (centro) e os voos nupciais de cupins dos quais os peixes se alimentam (banda externa). Indígenas Tuyuca, Rio Tiquié, Brasil (Aloisio Cabalzar, ISA, com permissão). 


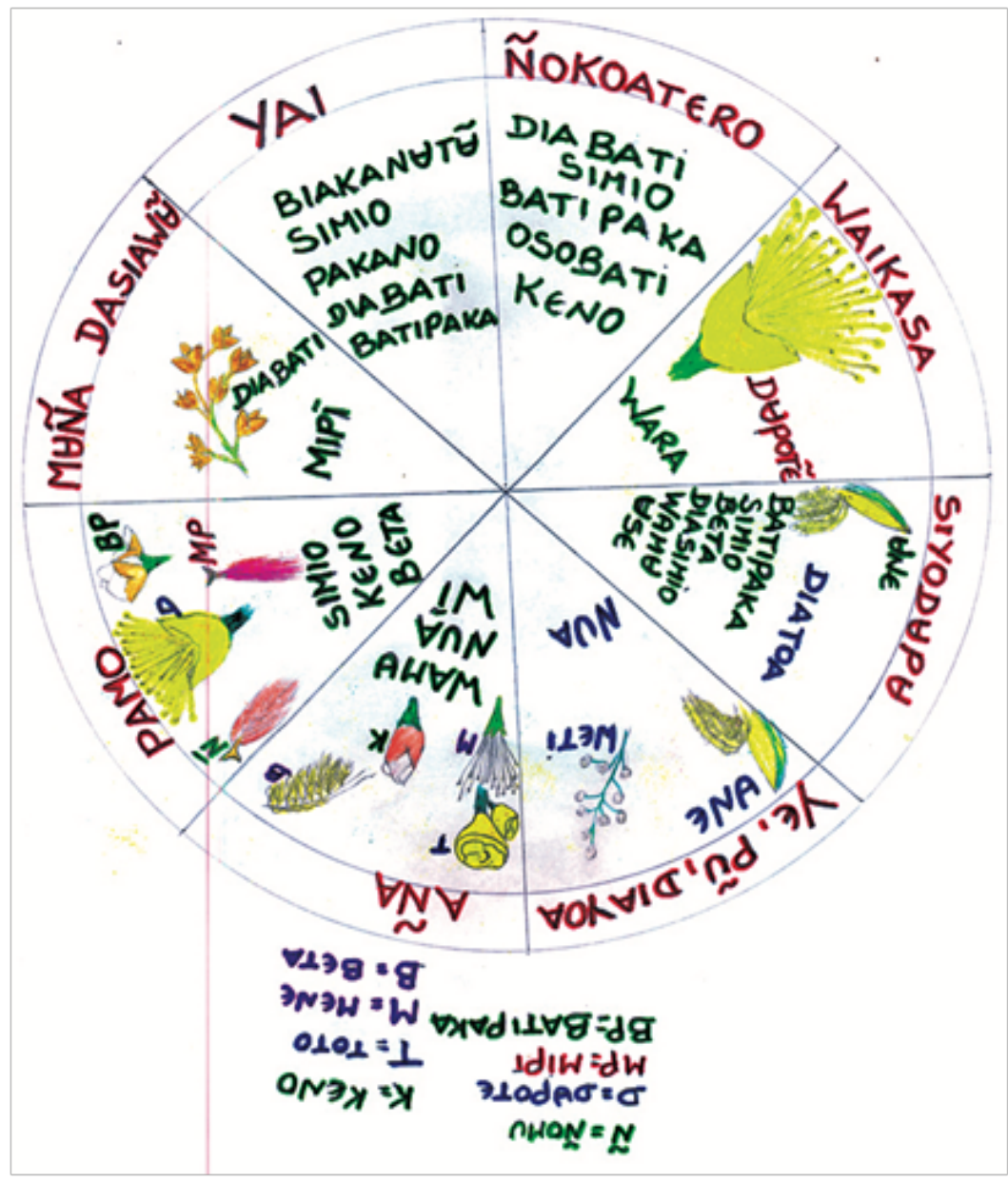

Figura 6: Calendário mostrando as estações de floração de diferentes árvores selvagens e cultivadas e espécies de palmeiras produzindo frutos comestíveis com as estações (anel exterior, vermelho) nomeado pelas constelações. Indígenas Tuyuca, Rio Tiquié, Brasil (Aloisio Cabalzar, ISA, com permissão).

O interesse contínuo na etnoastronomia, que começou pela primeira vez nos anos 1970, resultou em reedições brasileiras de várias obras clássicas com importante material antigo relacionado à 
Amazônia noroeste. Estes incluem Começos da arte na selva (KochGrünberg 2009 [1905]), uma tradução portuguesa de Anfänge der kunst im Urwald com desenhos de estrelas e constelações por artistas Mirití-Tapuyo, Kubeo e Siusi; o ensaio de Tastevin (2008 [1925]) sobre Boiassu, a grande serpente do céu dos povos do Rio Negro que corresponde ao Escorpião dos povos de fora; e um artigo dos astrônomos Lima e Mendonça Figeiroa (2010), que dá conta das contribuições do século XIX de Charles Frederick Hartt e José Vieira Couto de Magalhães, que estudaram o conhecimento astronômico dos povos do Rio Negro.

Embora nenhum deles tenha sido republicado nos últimos anos, dois outros trabalhos clássicos sobre astronomia do Rio Negro merecem menção aqui. O primeiro é 'A astronomia entre os índios' de Themistocles Pais de Souza Brasil. Que apareceu como parte da 'Introdução' de Magalhães aos Índios do Brasil de Rondon (1953). Sousa Brasil foi um engenheiro militar que acompanhou Rondon em suas visitas à Amazônia. Seu trabalho identifica onze constelações reconhecidas por grupos indígenas não identificados. Com toda a probabilidade, estes são grupos da região noroeste da Amazônia-Rio Negro. O segundo é A civilização indígena do Uaupés (1962) de Silva, que contém um relato do ciclo de constelação, tal como é entendido por um informante Piratapuia, material sobre o calendário da constelação de Tukano e dados sobre as estações do sacerdote missionário italiano Antonio Giacone, que viveu muitos anos entre os grupos tukanos na região do Alto Rio Negro.

Este posfácio destina-se simplesmente a ser uma atualização sobre o que foi publicado desde que meu próprio artigo apareceu pela primeira vez, e não como uma revisão completa da literatura. No entanto, vale a pena ressaltar que enquanto o foco do meu artigo foi sobre a cosmologia dos Barasana e seus vizinhos imediatos que vivem na região do Pirá-Paraná na Colômbia, o que emergiu na literatura desde então é que todos os povos que vivem na Região Rio Negro, Noroeste Amazônico, compartilham um padrão geral comum de conhecimento 
astronômico. Apesar da extrema diversidade linguística, os falantes de Tukano e Arawak e os grupos 'Makú', nômades que falam diferentes línguas isoladas, reconhecem as mesmas estrelas e constelações significativas e compartilham um entendimento comum de como elas se encaixam com as condições siderais, solares, lunares e ciclos ecológicos. Este ponto é bem apresentado na ampla pesquisa de Epps \& Oliveira (2013) sobre o conhecimento astronômico nessa região.

A pesquisa de Epps \& Oliveira revela que a tradição das estrelas dos falantes do Arawak do Rio Negro é semelhante à de seus vizinhos Tukano, mas difere bastante daquela dos falantes de Arawak em outros lugares na Amazônia. Isso sugere que a tradição de estrelas dos Arawak do Rio Negro provavelmente tem origens Tukano. Epps e Oliveira também chamam a atenção para a relativa falta de interesse pela astronomia exibida pelos grupos nômades Makú. Eles sugerem que isso pode se relacionar tanto com a preferência desses povos pela caça e coleta sobre a agricultura e à visão restrita sob a cobertura florestal fechada que essa preferência acarreta.

Em relação ao padrão geral comum de conhecimento astronômico compartilhado por povos do Noroeste Amazônico, o relato de Reichel-Dolmatoff (1982) de um arranjo de estrelas significativas entre os Desana, um arranjo correlacionado com estruturas análogas na arquitetura, cristais xamânicos, arquitetura cerebral e outros fenômenos, parece anômalo. Estruturas hexagonais desse tipo não parecem figurar em outros relatos mais recentes da tradição de estrelas dos Desana, incluindo aqueles de especialistas dos Desana.

Outro ponto a observar é que o que emerge destas diferentes publicações é um grau incomum de interesse em fenômenos astronômicos entre as populações da Amazônia Noroeste, um interesse que vai de mãos dadas com uma sofisticada tradição astronômica. $\mathrm{O}$ conhecimento astronômico é codificado principalmente na oralidade em uma rica e complexa tradição mitológica. Resta muito a explorar, principalmente com relação a histórias que se relacionam com os movimentos de Vênus e outros planetas. $\mathrm{O}$ conhecimento astronômico 
também é codificado na visualidade em desenhos e diagramas gravados como petróglifos em rochas, desenhados na areia, tecidos em cestaria, e pintados em cerâmica, casca, frentes de casa e outros suportes. Os desenhos que são produzidos no papel em relação com os programas de educação e gestão de recursos representam uma transformação moderna dessa tradição muito mais antiga.

A elaboração e sofisticação desta tradição astronômica amazônica do noroeste parece ter poucos paralelos em outras partes das planícies da América do Sul. Ao lado de suas tradições orais extraordinariamente esotéricas, sacerdotais, um elaborado conhecimento astronômico pareceria ser um indicador para uma ligação, originalmente sugerida por Lévi-Strauss $(1973,272)$, entre os habitantes do alto rio Negro e as civilizações arqueológicas mais complexas do meio da Região Amazônica.

\section{Notas}

Este texto é uma tradução de dois artigos publicados anteriormente por Stephen Hugh-Jones. O primeiro intitulado: The Pleiades and Scorpius in the Barasana Cosmology publicado originalmente em 1982 nos Anais da Academia de Ciências de Nova York. O segundo intitulado: Postscript: Thirty-three years on publicado na revista JSA 1.1 (2015) 127-132. Esta tradução recebeu uma revisão do autor e as notas e bibliografias foram atualizadas, ao que agradecemos a Stephen Hugh-Jones. (Nota do Editor).

1 Cf. Koch-Grünberg 2009: pp. 58-63, figs. 55, 56.

2 Cf. Blandon 1961: 29-32; Giacone 1949: 98, 117-8; Paes de Souza Brasil 1938: 61-63; Reichel-Dolmatoff 1971: 71,73-74,117,199; Bruzzi da Silva 1962: 258-63; Silverwood-Cope 1990: 180; Stradelli 1921: 1-768.

3 Koch-Grünberg 1911; 1912-16.

4 A pesquisa entre os Barasana foi realizada de setembro de 1968 à dezembro de 1971 e de Julho à dezembro de 1979, graças aos auspícios do Social Science Research Council da Inglaterra.

5 Hugh-Jones 1979: 145 identifica incorretamente a Constelação Adze como fazendo parte do cinturão de Orion com Bellatrix ( $\alpha$ Orionis) e Betelgeuse ( $\gamma$ Orionis). 
6 Estrelas e constelações foram identificadas e apontadas com a ajuda de uma lanterna, com um número significativo de informantes. As identificações foram checadas com a ajuda de um mapa das estrelas no campo e subsequentemente confrontadas com Menzel 1964.

7 Os períodos do aparecimento e desaparecimento das estrelas e constelações foram tiradas das tabelas fornecidas pelo Dr. Anthony Aveni (1972). Para evitar distorções da realidade etnográfica não colocamos os termos numéricos.

8 Patrice Bidou, comunicação pessoal.

9 Cf. Tastevin, 1925.

10 Koch-Grünberg 2009:123.

11 Hugh-Jones 1979: 223-24.

12 Patrice Bidou, comunicação pessoal.

13 Para os detalhes dos argumentos sobre a cera-breu, a mulher-xamã e a menstruação relacionados às Plêiades, conferir Hugh-Jones, 1979.

14 Cf. S. Hugh-Jones, 1979:227-33, 287-93.

15 Sobre os ornamentos de penas e danças rituais e ciclos temporais ver: HughJones 1979: 227-33, 287-93; veja também Hugh-Jones, 2015.

\section{Referências}

AEITU, 2005. Wiseri makane, Niro Makane. Casa de Transformacao - Origem da vida ritual Utapinopona-Tuyuka. São Gabriel da Cachoeira/São Paulo: AEITU/ Instituto Socioambiental.

AEITY \& ACIMET, 2008. Mari kahtiri pati kahse ukuri turi. São Gabriel da Cachoeira/ São Paulo: Federação das Organizações Indígenas do Rio Negro, Associação Escola Indígena Tukkano Yupuri, Associação das Comunidades Indígenas do Médio Tiquie/Instituto Socioambiental.

ARIAS DE GRIEF, J. \& REICHEL, E. (ed.). 1987. Etnoastronomias Americanas. Bogotá: Universidad Nacional de Colombia.

AVENI, A.F. 1972. "Astronomical tables intended for use in astroarchaeological studies," American Antiquity, 37: 531-40.

AVENI, A. \& URTON, G. (ed.). 1982. Ethnoastronomy and Archaeoastronomy in the American Tropics. Annals of the New York Academy of Sciences 385. New York: New York Academy of Sciences.

BLANDON, J.M. 1961. "Sobre los Piratapuyo," Semisiones, 86:29-32.

CABALZAR, A., 2008. Filhos da Cobra de Pedra: Organização social e trajetórias tuiuca no rio Tiquie (noroeste amazônico). São Paulo/Rio de Janeiro: Editora Unesp/ ISA/Nuti. 
CABALZAR, A \& AZEVEDO, M. 2010. "Manejo ambiental e pesquisa do calendário anual no rio Tiquié". In CABALZAR, A (ed.): Manejo do mundo: Conhecimentos e práticas dos povos indígenas do Rio Negro, pp. 46-55. São Gabriel/ São Paulo: Federação das Organizações Indígenas do Rio Negro/Instituto Socioambiental.

CARDOSO, W. T., 2007. O Céu dos Tucanos na Escola Yupuri: Construindo um calendário dinâmico. Tese de Doutorado. São Paulo: PUC.

CORREA, F. R., 1987. "Tiempo y espacio en la cosmologia de los Kubeos". In ARIAS DE GRIEF, J. \& REICHEL, E. (eds.): Etnoastronomias Americanas, pp. 137-168. Bogota: Universidad Nacional de Colombia.

COUTO DE MAGALHAES, A. 1953. "Introdução". In RONDON, C. M (ed.): Índios do Brasil - VOL III: Norte do Rio Amazonas. Rio de Janeiro: Ministério da Agricultura - Conselho Nacional de Proteção aos Índios.

DIAKURU \& KISIBI (Fernandes, A. C. \& Fernandes, D. M.). 2006. Bueri Kadiri Marĩriye: Os ensinamentos que não se esquecem. Santo Antônio/São Gabriel da Cachoeira: Rio Tiquie/UNIRT/FOIRN.

EPPS, P. \& OLIVEIRA, M. 2013. "The Serpent, the Pleiades, and the Onelegged Hunter: Astronomical Themes in the Upper Rio Negro". In EPPS, P. \& STENZEL, K. (eds.): Upper Rio Negro: Cultural and Linguistic Interaction in Northwestern Amazonia, pp. 91-128. Rio de Janeiro: Museu do Índio FUNAI/Museu Nacional.

GIACONE, A. 1949. Os Tukanos e Outras Tribus do Rio Uaupés Affluente do NegroAmazonas. São Paulo: Imprensa Oficial do Estado.

HUGH-JONES, S. 1979. The Palm and the Pleiades. Ritual and Cosmology in Northwest Amazonia. Cambridge: Cambridge University Press.

. 2015. "A origem da noite e porque o sol é chamado do "folha de caraná", Revista de Sociologia e Antropologia, 5(3):659-698.

KOCH-GRÜNBERG, T. 1911. "Aruak-Sprachen Nordwest Brasiliens und der Angrenzenden Gebiete," Mitteilungen der Anthropologischen Gesellschaft in Wien, 41: 33-153, 203-82.

1912-16. "Betóya-Sprachen Nordwest Brasiliens und der Angrenzenden Gebiete," Anthropos, 7(1912):429-62; 8(1913):944-77; 9(1914):151-95, 569-89, 812-32; 10-11(1916):114-58, 421-49. . 2009. Começos da Arte na Selva. Manaus: EDUA.

2009 [1905]. Comecos da Arte na selva. Desenhos manuais de indigenas colecionados por Dr. Theodor Koch-Grunberg em suas viagens pelo Brasil. Manaus: Universidade Federal do Amazonas/IGHA.

LEVI-STRAUSS, C., 1973 [1966]. From Honey to Ashes: Introduction to a Science of Mythology, vol. 2. New York: Harper \& Row.

LIMA, F. P. \& MENDONCA FIGEIROA, S. F. 2010. "Etnoastronomia no Brasil: a contribuição de Charles Frederick Hartt e Jose Vieira Couto de Magalhães". Boletim do Museu do Para Emilio Goeldi (Cienciais Humanas), 5(2):295-313.

MENZEL, D.H. 1964. A Field Guide to the Stars and Planets. Boston: Houghton Mifflin. 
NAHURI \& KUMARO. 2003. Dahsea Hausiro pora ukũshe wiophesase mera bueri turi - Mitologia Sagrada dos Tukano Hausiro Pora. São Gabriel da Cachoeira: Unirt/ FOIRN.

OLIVEIRA, M. 2010. Astronomia Tukano. (http://pib.socioambiental.org/pt/c/nobrasil-atual/modos-de-vida/astronomia-tukano; acesso em 12/2014).

OliveirA, M., CARDOSO, W. \& AZEVEDO, H. V. V. B. 2010. "Calendário astronômico, ecológico, socio-econômico e ritual do Meéio Tiquie: Conhecimentos para a educação e o manejo". In CABALZAR, A. (ed.): Manejo do Mundo: Conhecimentos e práticas dos povos indígenas do Rio Negro, pp. ${ }^{* * * * * *}$. São Gabriel da Cachoeira/São Paulo: Federação das Organizações Indígenas do Rio Negro/Instituto Socioambiental.

PAES DE SOUZA BRASIL, T. Incolas Selvicolas. São Paulo: Leuzinger S. A.

REICHEL, E., 1987. "Astronomia yukuna-matapi". In ARIAS DE GRIEF, J. \& REICHEL, E. (eds.): Etnoastronomias Americanas, pp. 193-232. Bogota: Universidad Nacional de Colombia.

REICHEL-DOLMATOFF, G., 1982. "Astronomical Models of Social Behavior among some Indians of Colombia”. In AVENI, A. F. \& URTON, G. (eds.): Ethnoastronomy and Archaeoastronomy in the American Tropics, Annals of the New York Academy of Sciences, pp. 385: 165-181. New York: New York Academy of Sciences.

REICHEL-DOLMATOFF, G. 1971. Amazonian Cosmos. The Sexual and Religious Symbolism of the Tukano Indians. Chicago/London: University of Chicago Press.

RIBEIRO, B. G. \& KENHIRI, T. 1987. "Chuvas e constelacões". Ciência Hoje, 6(36):26-35.

ROJAS SABANA, F. A. 1997. Ciencias naturales en la mitologia Curripaco. Bogotá: Fundacion Etnollano.

RONDON, C. M. da S. 1953. Índios do Brasil, Vol. III: Norte do Rio Amazonas. Rio de Janeiro: Ministério da Agricultura - Conselho Nacional de Proteção aos Índios.

ROMERO RAFFO, M. 2003. Malikai, el canto del malirri: formas narrativas en un mito amazonico. Bogota: Cerec.

SILVA, A. Bruzzi A. 1962. A civilizacao indígena do Uaupes. Sao Paulo: Linográfica.

SILVERWOOD-COPE, P. 1990. Os Makú. Povo Caçador do Noroeste da Amazônia. Brasília: UNB.

STRADELLI, E. 1921. "Vocabulários da Língua Geral - Portuguez-Nheêngatú-Portuguez," Revista do Instituto Historico e Geografico Brasileiro, 158:1-768.

TASTEVIN, P.C. 1925. "La legende de Bóyusú en Amazonie, texte tupy on neêngatu," Revue d'Ethnographie et des Traditions Populaires, 6:171-206.

2008 [1925]. "A lenda de Boiacu na Amazonia". In FAULHABER, P. \& MONSERRAT, R. (eds.): Tastevin e a Etnografia Indigena. Coletânea de traduções de textos produzidos em Tefé (AM), pp. 137-183. Rio de Janeiro: Museu do Índio - FUNAI. 
VON HILDEBRAND, M. 1987. "Datos etnograficos sobre la astronomia de los indigenas Tanimuka del noroeste Amazonico". In ARIAS DE GRIEF, J. \& REICHEL, E. (eds.): Etnoastronomias Americanas, pp. 233-254. Bogotá: Universidad Nacional de Colombia.

\begin{abstract}
The text presents ethnographic details of the astronomical system of the Amerindians of the region of the Amazon Northwest according the understanding of the Barasana of the Pirá-Paraná River of the watershed of the Uaupés River in Colombian territory. The Barasana believe that the universe is composed of three basic layers: heaven, earth and the underworld expressed as models of earthly experience, so that each is described as having forests and rivers and inhabited by people in large communal houses or Malocas For the Barasana, astronomical knowledge is not simply a cognitive system, but also one that gives to human power over the natural world. The last part of the article is a review of the updated literature on the cultural astronomy of the region known as the Upper Rio Negro.
\end{abstract}

Keywords: Barasana, Northwest-Amazonian, Ethnoastronomy, Pleiades, Astronomy-Cultural.

Recebido em dezembro de 2016. Aprovado em abril de 2017.

Tradução: Hermilo Santana. Revisão Técnica: Renato Athias. 